\title{
900 Megahertz Dalga Frekansına Sahip Elektromanyetik Alanın Biyolojik Sistemler Üzerindeki Olası Etkilerine Bilimsel Yaklaşım: Derleme
}

\section{The Scientific Approach to the Possible Effects of Electromagnetic Fields With 900. Megahertz Frequency Waves on Biological Systems: Review Sibel TÜREDi $1{ }^{1}$, Hatice HANCl ${ }^{2} \mathbb{D}$, Ersan ODACl ${ }^{2 *}$}

1 Harran Üniversitesi, Tıp Fakültesi, Histoloji ve Embriyoloji Anabilim Dalı, Şanlıurfa

2 Karadeniz Teknik Üniversitesi, Tıp Fakültesi, Histoloji ve Embriyoloji Anabilim Dalı, Trabzon

Öz.

Günümüzde cep telefonları/akıllı telefonların kapasitesinin artması ve fiyatlarındaki azalma ile birlikte cep telefonlarının kullanımı da hızla yaygınlaşmıştır. Bununla birlikte, her teknolojik ilerlemenin ve aşıı kullanımının olumsuz bir yönü olabileceği düşüncesi ile pek çok araştırmacı elektromanyetik alanın insan vücudundaki etkilerini araştırmaya yönelmiştir. Elektromanyetik alanın insan vücudundaki pek çok sistemi olumsuz etkileyerek özellikle kanser, infertilite, sinir dokusu dejenerasyonu, kardiyolojik hasar gibi pek çok hastalığa sebep olabileceği rapor edilmiştir. Ayrıca Uluslararası Kanser Araştırma Merkezi çok düşük frekanslı elektromanyetik alanın insanda sınırlı kanıta sahip kanserojen ve hayvan deneylerinde "yeterli kanserojen" olarak tanımlanan grup 2B'de sınıflandırmıştır. Bu nedenle, cep telefonu kaynaklı radyasyon maruziyetinin neden olduğu biyolojik etkileri incelemek son derece ciddi ve zor bir araştırma süreci olarak görünmektedir. Bu çalışmada, elektromanyetik alan maruziyeti konusunda toplum bilincine katkı sağlamak ve araştırmacılara yeni ve farklı fikirler verilebilmesi adına elektromanyetik alanın olası biyolojik etkileri, incelenen literatür kaynaklar seviyesinde derlenmiştir.

Anahtar Kelimeler: Elektromanyetik Alan, Cep Telefonu, İnfertilite, Nöron Sayısı, Kalp Sıçan

\section{Abstract}

The use of mobile phones has become widespread rapidly with the increase in the capacity of mobile phones/smart phones and the decrease of prices in novadays, However, many researchers have turned to the effects of electromagnetic fields on the human body whit the idea that the overuse of every technological advance will be have a negative aspect. A large number of studies investigating EMF exposure and the health effects of it focused on particularly cancer, reproductive health, diseases caused by nevre tissue necrosis and hearth diseases. Extremely low frequency magnetic fields has been classified in group 2B which is the category of limited evidence of carcinogenity in humans and sufficient evidence of carcinogenity in experimental animals by The International Agency for Research on Cancer. Therefore, to examine the biological effects caused by cell phone induced radiation exposure appears as an extremely serious and difficult research process. In this study, possible biological effects of electromagnetic field were reviewed in the light of the literature sources, in order to community awareness about exposure and to give different ideas to researchers.

Key words: Electromagnetic Field, Cell Phone, Infertility, Neuron Count, Heart, Rat
Sorumlu Yazar I

Corresponding Author

Dr. Öğr. Üyesi Sibel Türedi

Harran Üniversitesi, Tıp Fakültesi

Histoloji ve Embriyoloji Anabilim Dalı, 63000 , Şanlıurfa, Türkiye

Tel +90 4143181491

e-mail:

sibelturedi3361@hotmail.com; sibelturedi@harran.edu.tr

Geliş tarihi / Received: 17.01.2020

Kabul tarihi / Accepted: 03.03.2020

DOI: 10.35440/hutfd. 676567

* Prof. Dr. Ersan Odacı hocamız vefat etmiştir 


\section{Giriş}

Yaşam alanımızda bulunan radyo ve televizyon vericileri, cep telefonları, uydu iletişim sistemleri, elektrikli ev aletleri, baz istasyonları ve bilgisayarlar gibi tüm elektronik eşyalar çalışırken elektromanyetik alan oluşturmaktadır $(1,2)$. Mobil internet ve kablosuz erişimin kolay elde edilebilir olmasının yanı sıra söz konusu cep telefonları/akıllı telefonların kapasitesinin artması ve fiyatlarındaki azalma ile birlikte cep telefonlarının kullanımı da hızla yaygınlaşmışıı. Bununla birlikte, her teknolojik ilerlemenin ve aşırı kullanımının olumsuz bir yönü vardır. Özellikle genç nüfusun cep telefonu kullanma oranındaki artış düşünüldüğünde gençlerin çok ciddi bir tehlikeyle karşı karşıya olduğu bir gerçektir (2-5). Son on yılda modern iletişim teknolojilerinin hızla ilerlemesi ile birlikte hayatımızın ayrımaz bir parçası haline gelen cep telefonlarının güncelliğini koruyan en önemli elektromanyetik alan (EMA) kaynaklarından biri olduğu belirtilmektedir (6). Uluslararası Kanser Araştırma Merkezi (IARC) çok düşük frekanslı manyetik alanı insanda sınırlı kanita sahip kanserojen ve hayvan deneylerinde "yeterli kanserojen" olarak tanımlanan 2B grubunda sınıflandırmıştır $(7,8)$. Cep telefonu şirketleri abonelerini sürekli olarak ürünlerinin güvenliği konusunda güvence altına alsa da, cep telefonlarının biyolojik sistemler üzerindeki olumsuz etkilerini gösteren hayvan ve insan deneylerine dayanan raporlar gün geçtikçe artmakta $(1,9,10)$ ve özellikle kanser, üreme sağlığı, sinir dokusu bozulması ile seyreden hastalıklar ve kalp hastalılarına odaklanılmaktadır (7).

Cep telefonu telekomünikasyon sistemlerindeki modern gelişmeler yüksek enerjili radyofrekans (RF) dalgaları ile korelasyon halinde olan sinyal frekansındaki bir artış ile ilişkilidir. Cep telefonu sisteminin ilk gelişimi 1980 yılında 902.5 Megahertz'de (MHz) çalışan Analog NMT (Nordic Mobile Telephone) sistemidir. Daha sonraki yıllarda 902.4 $\mathrm{MHz}$ RF ile çalışan GSM (global system of mobile communications) operatörleri ve devamında $1800 \mathrm{MHz}$ bir RF aralığında düşük manyetik alanla ilişkili DCS (Digital Cellular System) operatörleri ortaya çıkmıştır. (11). Ayrıca, belirli ülkelerde radyo dalgaları farklı frekans bandında iletilir. Amerika Birleşik Devletleri ağ operatörleri 850/1900 MHz'de çalışırken çoğu Avrupa ve Asya ülkeleri operatörleri de 900/1800 MHz hızında çalışmaktadır. TÜIK 2019 yılı istatistiksel verileri incelendiğinde 2004-2019 yılları arasındaki göre cep telefonu kullanımındaki ciddi derecedeki artış (12) grafiği belirgin şekilde dikkat çekmektedir (Grafik 1). Cep telefonu kullanımındaki artış ile özellikle GSM 900 sisteminin daha yaygın kullanılmasından dolayı bu çalışmada 900 MHz'lik EMA maruziyetinin biyolojik etkilerinin değerlendirilmesi yapılmıştır.

EMA, etkisine göre iyonize ve non-iyonize elektromanyetik radyasyon şeklinde iki ana başılık alıında toplanabilir. İyonize radyasyonlar, enerjisini, içinden geçtiği ortama aktararak ortamdaki atomları iyonlaştırabilecek enerjiye sahip olan türdedir. Bu ışınlara fazla maruz kalmak, hücre organellerinin hasara uğramasına ve DNA zincirinin bozulmasına yol açabileceğinden dolayı tehlikelidir. (13). Non-iyonize radyasyonlar ise içinden geçtiği ortamdaki atom bağlarını iyonlaştıramayacak kadar düşük enerjilidir. Cep telefonları da iyonize olmayan radyasyon grubu içerisindedir. Bu alanlar mesafe, güç ve maruz kalma süresi gibi çeşitli faktörlere bağlı olarak vücutta ısıl etki (ISı artışı) oluştururlar; hatta bazı uzmanlarca biyolojik etkilere de sebep olabileceği öne sürülmektedir (13). Patofizyolojik mekanizması tam olarak bilinmemekle birlikte insan vücudu üzerinde iki türlü biyolojik etkiden bahsedilmektedir. Birincisi, RF'nin doku veya vücut ısısında bir artışa yol açabilecek ısıtma özelliklerine sahip olduğu ve özellikle yüksek frekanslarda meydana gelen "termal etki" etkidir. Termal etkiler hücre fonksiyonunun bozulmasına ve hasar gelişmesine neden olabilir. İkincisi, vücut emiliminden oluşan elektriksel akımının geçişine bağı olarak hücre zarı bütünlüğünün bozulmasıyla ortaya çıkan "termal olmayan etki" dir. RF kaynaklı EMA, nöronların elektrik aktivitesini, genomik yanıtlarını, nörotransmitter dengelerini, kan-beyin bariyerinin geçirgenliğini etkiler $(14,15)$.

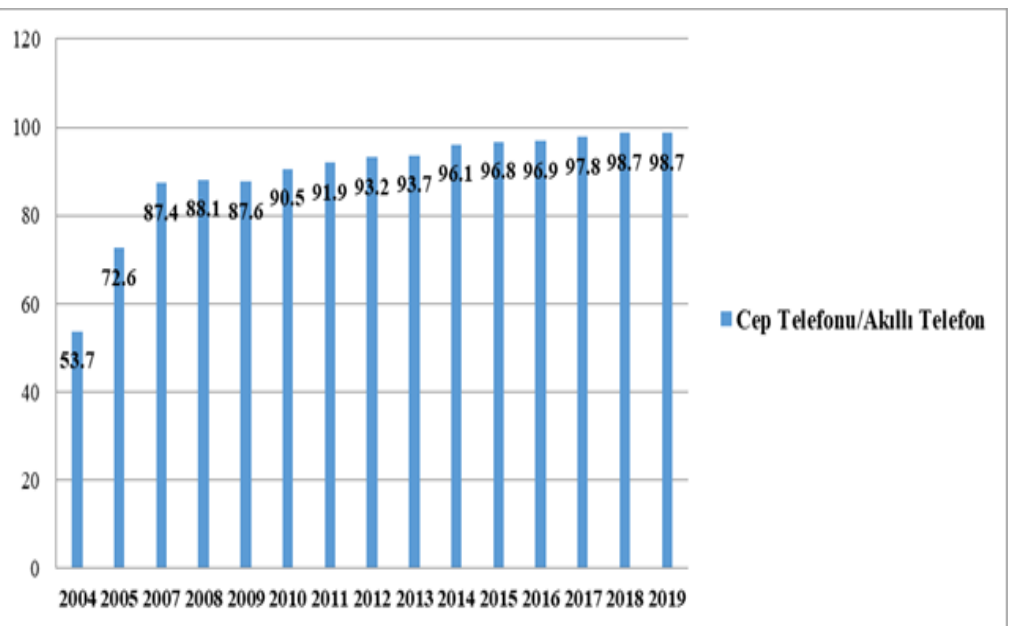

Grafik 1. TÜIK, Hanehalkı Bilişim Teknolojileri Kullanım Araştırması, 2004-2019

İnsan vücudunun çeşitli bölgeleri enerjinin emilimi/soğurulması açısından artan frekansa göre farklı karakterler gösterir. Soğurulan elektromanyetik alan dokuda bir sıcaklık artışına neden olarak doku hasarına neden olabilir ve EMA'nın bu hasar, doku ile yaptığı etkileşimin türüne, dokuda soğurulan enerji miktarına ve maruz kalma süresine göre değişkenlik gösterebilir. Bu şekilde dokunun birim kütlesinde soğurulan enerji "doz" olarak tanımlanır ve özellikle dış ortamdaki enerji miktarından çok, enerjinin dokudaki soğurulma oranı önemlidir (16). Bu durumu içeren bir "Özgül Soğurma Oranı" birimi; SAR=Enerji / (Kütle x Zaman) $=J$ oule $/ \mathrm{Kg} . \mathrm{s}=$ Watt $/ \mathrm{kg}$ olarak tanımlanmışır (17). İnsan sağlığı ile ilgili EMA etkilere ait limitleri belirleyen ulus- 
lararası kuruluşlardan en önemlileri "Uluslararası İyonlaştırICI Olmayan Radyasyon Komitesi (INIRC)" ve "Uluslararası Radyasyondan Korunma Kurumu (IRPA)"dır. Bu kuruIuşların belirlediği, temel limitler ve türetilmiş limitler olmak üzere iki tip limit vardır. Temel limit olarak ortalama insanda vücut sıcaklığını $1^{\circ} \mathrm{C}$ arttıracak elektromanyetik enerji soğurulmasının zararlı olduğu düşüncesinden yola çıkılmıştır. Uluslararası İyonlastııı ı Olmayan Radyasyondan Korunma Komitesi (ICNIRP) genel halk için temel limiti 50 kat güvenlik payı ile $0.08 \mathrm{~W} / \mathrm{kg}$, günün belirli saatlerinde bulunulan iş yerleri için 10 kat güvenlik payı ile $0.4 \mathrm{~W} / \mathrm{kg}$ SAR değeri olarak belirlemiştir. Ölçülebilir türetilmiş limitlere geçildiğinde $900 \mathrm{MHz}$ ve $1800 \mathrm{MHz}$ Groupe Speciale Mobile (GSM) sistemleri için sınır değerler, sırasıyla; $42 \mathrm{~V} / \mathrm{m}$ ve 59 $\mathrm{V} / \mathrm{m}$ (güç yoğunluğu olarak $4.5 \mathrm{~W} / \mathrm{m}^{2}$ ve $9 \mathrm{~W} / \mathrm{m} 2$ ) olarak belirlenmiştir $(18,19)$. Türkiye'de genel yaşam alanlarında GSM 900 ve $1800 \mathrm{MHz}$ sistemleri için ICNIRP esas alınarak hazırlanan sınır değerler Tablo 1'de gösterilmiştir (20). Günlük yaşantımızın vazgeçilmez bir parçası haline gelen cep telefonları, pek çok fonksiyonel özellikleri ile yaşantımızı kolaylaştırmakla birlikte, neredeyse bağımısı haline geldiğimiz bu teknolojinin uzun süre kullanıldığında ya da gebeliğin herhangi bir döneminde kontrolsüz kullanıldığında, insan sağlığı üzerine ne gibi etkileri olabileceği ciddi bir endişe ve merak kaynağıdır. Bu çalışmada, pek çok bilim dalının son derece popüler bir araştırma konusu olan cep telefonlarının biyolojik etkileri, sinir sistemi kardiyovasküler sistem ve gonadal hasarı üzerine gözden geçirimiş ve muhtemel olumsuz etkileri değerlendirilmiştir.

\section{EMA ve Sinir Sistemi Etkileri}

Sinir sistemi tüm aktivitesini nöronal alt sistemler içinde veya arasında sınırlanma ve uyarılma süreçlerinin dinamik etkileşiminin sonucunda gerçekleştirir. Bu etkileşimde herhangi bir nedenden dolayı meydana gelen yetersizlik patolojik olarak sonuçlanabilir. Kan-beyin bariyeri, kan akımı ile beyin parankimi arasındaki moleküllerin geçişini kısıtlayan vasküler endotel hücreleri ve perivasküler astrositlerden oluşan karmaşık bir hücresel sistemdir ve MSS açısından hayati rol oynar. Kan beyin bariyeri, beyin ısısında artış, beyin kılcallarında yüksek ozmolaritede bulunan maddelerin varlığı gibi çeşitli etmenlerin varlığında bütünlüğünü kaybedebilmektedir. Behari (2003) yapmış olduğu çalışmasında mikrodalga alanlarının kan beyin bariyerinin geçirgenliğinde değişikliğe yol açtığını ifade ederken (21), Nittby ve arkadaşlarının (2009) çalışma sonuçları da bu çaIışmayı destekler nitelikte olup, GSM-900 cep telefonu kaynaklı elektromanyetik alana maruziyetin memeli beyninde kan-beyin bariyeri geçirgenliğini artırdığı ve böylece nöronal dejenerasyona neden olduğu rapor edilmiştir (22).

Memeli hipokampusunda Dentate girusun (DG) hafıza örüntüsünün ayrımında görev aldığı, ortogonal tanımlamaların oluşumunda aracılık ettiği ve yaşam boyunca nörogenezis merkezi olarak görev aldığı varsayımlar arasındadır
(23). $900 \mathrm{MHz}$ EMA'ya (prenatal dönem boyunca/hergün/günde bir saat) maruz kalmıs yavruların DG'de meydana getireceği etkilerin postnatal 4. haftada incelendiği bir çalışmada, DG'sindeki granüler hücre sayısının anlamlı derecede azaldığı ve hipokampusun bu bölgesindeki nörogenezisin negatif olarak etkilendiği bildirilmiştir (24). Baş ve arkadaşlarının (2013) yapmış oldukları çalışmalarında prenatal dönem EMA maruziyeti sonucunda postnatal dönemde Cornu Ammonis'in piramidal hücre sayısında anlamlı derecede azalma olduğu ve piknotik hücrelerle hücre kaybının açıkça görülebildiği ifade edilmiştir (25). Kerimoglu ve arkadaşlarının (2016) ergenlik boyunca, uzun süreli ve sürekli $900 \mathrm{MHz}$ elektromanyetik alana maruz kalan erkek sıçanların hipokampus morfolojisini inceledikleri çaIışmalarında, piramidal hücre sayısında azalma meydana geldiği ve çalışmanın sonuçlarına bakılarak ergenlik döneminde maruz kalınan EMA'nın beyin üzerinde meydana getirdiği değişikliklerin erişkin dönemde halen gözlemlenebilir olduğunu vurgulamışlardır (26). Balaguru ve arkadaşları (2012) elektromanyetik alanın kan-beyin bariyerini zayıflatarak MSS'de meydana getirdiği etkiler için spinal cordun bir EMA anteni olarak görev yapabileceğini öne sürmektedirler ve bu durumda spinal kordun EMA'dan etkilenmesinin kuvvetle muhtemel olduğunu söylenilebilir (27). Odacı ve arkadaşlarının (2013) çalışmalarında gebelik dönemlerinin 13-21. günleri arasında EMA etkisi uyguladıkları sıçan yavrularının spinal kord dokusunda ciddi morfolojik hasar ile birlikte, öğrenme ve motor davranışların etkilendiği rapor edilmiştir (28). Anmari ve arkadaşları da (2008) yapmış oldukları çalışmalarında bu çalışmayı destekler nitelikte olup, statik manyetik alanların duygusal değişimlerin ve bilişsel bozuklukların (özellikle dikkat bozuklukları) meydana gelmesine neden olduğunu belirtmiştir (29). Kerimoğlu ve arkadaşlarının (2016) ergenlik dönemleri boyunca günde 1 saat süre ile $900 \mathrm{MHz}$ elektromanyetik alana maruz kalan sıçanların lomber omurilik morfolojisini inceledikleri çalışmalarında gri maddede düzensizlik ve vakuolizasyon, beyaz maddenin gri madde içine infiltrasyonu, glial hücre apoptozisinde artış olduğu ifade edilmiştir (30). Literatürde yer alan bazı çalışmalar, EMA'nın doğum öncesi uygulamasını takiben serebellar kortekste Purkinje hücrelerinin gelişiminin etkilenebileceğini göstermiştir. Sönmez ve arkadaşları (2010) dişi sıçan serebellumunu stereolojik olarak inceledikleri çalışmalarında gebelikte maruz kalınan EMA'nın sıçan Purkinje hücre sayısında azalmaya neden olduğunu rapor etmişlerdir (31). Yine gebelik döneminde $900 \mathrm{MHz}$ EMA'ya maruz bırakılan sıçanların dişi yavrularının postnatal 32. günde beyinciklerinin incelendiği bir diğer çalışmada da EMA maruziyeti sonucunda Purkinje hücre diziliminde bozulma ve Purkinje hücre sayısında anlamlı derecede azalma olduğu, piknotik hücreler ve koyu sitoplazmalı nöronların gözlemlendiği ifade edilmiştir (32). Haghani ve arkadaşlarının (2013) yapmış olduğu, prenatal EMA maruziyetinin sıçan yavrularının 
serebellumu üzerindeki potansiyel etkilerini araştırdıkları çalışmalarında ise EMA maruziyetinin Purkinje hücrelerinde elektrofizyolojik değişikliklere yol açtığı ifade edilmiştir (33).

Tablo 1. Türkiye'de kontrolsüz etkilenme için sınır değerler

\begin{tabular}{|c|c|c|c|c|}
\hline & \multicolumn{4}{|c|}{ Frekans Aralığı } \\
\hline & \multicolumn{2}{|c|}{$900 \mathrm{MHz}$} & \multicolumn{2}{|c|}{$1800 \mathrm{MHz}$} \\
\hline & $\begin{array}{l}\text { Tek bir cihaz } \\
\text { için sınır de- } \\
\text { ğer }\end{array}$ & $\begin{array}{l}\text { Ortamın toplam } \\
\text { sınır değeri }\end{array}$ & $\begin{array}{l}\text { Tek bir cihaz } \\
\text { için sınır de- } \\
\text { ğer }\end{array}$ & $\begin{array}{l}\text { Ortamın top- } \\
\text { lam sınır de- } \\
\text { ğeri }\end{array}$ \\
\hline $\begin{array}{l}\text { Elektrik } \\
\text { Alan } \\
\text { şiddeti }\end{array}$ & $10.23(\mathrm{~V} / \mathrm{m})$ & $41.25(\mathrm{~V} / \mathrm{m})$ & $14.47(\mathrm{~V} / \mathrm{m})$ & $58.34(\mathrm{~V} / \mathrm{m})$ \\
\hline $\begin{array}{l}\text { Manyetik } \\
\text { Alan } \\
\text { şiddeti }\end{array}$ & $0.027(\mathrm{~A} / \mathrm{m})$ & $0.111(\mathrm{~A} / \mathrm{m})$ & $0.038(\mathrm{~A} / \mathrm{m})$ & $0.157(\mathrm{~A} / \mathrm{m})$ \\
\hline $\begin{array}{l}\text { Güç } \\
\text { yoğunluğu }\end{array}$ & $0.28\left(\mathrm{~W} / \mathrm{m}^{2}\right)$ & $4.5\left(\mathrm{~W} / \mathrm{m}^{2}\right)$ & $0.56\left(\mathrm{~W} / \mathrm{m}^{2}\right)$ & $9.0\left(\mathrm{~W} / \mathrm{m}^{2}\right)$ \\
\hline
\end{tabular}

$\mathrm{MHz}$, Megahertz; V/m, Volt/metre; A/m, Amper/metre; W/m2, Watt/metre kare

Periferik sinir sistemi (PSS) vücudun doku ve organları ile beyin ve spinal kord arasında duyusal ve motor (efektör) bilgi taşımaktadır (34) ve bu yapıların normal işleyişi vücut fonksiyon bütünlüğü için oldukça önemlidir (35). Choi ve arkadaşlarının (2013) yaptıkları bir çalışmada EMA maruziyeti sonucunda miyelinli akson dejenerasyonu ve miyelinizasyonu tamamlanmamış sinir liflerinin gözlemlendiği ifade edilmiştir (36). Çomelekoğlu ve arkadaşlarının EMA'nın sıçan siyatik sinirine olan etkilerini inceledikleri çalışmalarında 4 hafta süre ile günde bir saat EMA'ya maruz kalan sıçanların sinir aksiyon potansiyelinde azalma gözlemlenmiştir. Ek olarak EMA etkisine maruz kalan sIçanların siyatik sinir dokularında dejenere miyelinli sinir liflerine rastlandığı ve akson çapı/sinir lifi çapı oranlarında artış gözlemlendiği belirtilmiştir (37). Bu çalışmalardan yola çıkılarak EMA'nın periferik sinir sistemine ait yapılarda meydana getirdiği morfolojik değişikliklerin PSS'ye bağlı fonksiyonel görevlerin yerine getirilmesinde aksaklıklara sebebiyet verebileceği söylenebilir.

Literatürde yer alan bazı çalışmalarda ise yüksek frekanslı elekromanyetik alanların meydana getirdiği etkilerin aksine düşük frekanslı EMA'nın nöron gelişimi ve farklılaşması üzerine olumlu etkileri olabileceği görüşü yer almaktadır. Yapılan bir çalışmada düşük frekanslı EMA $(1 \mathrm{mT}, 50 \mathrm{~Hz})$ etkisine maruz bırakılan fare hipokampusunda nörogenezisin uyarıması ile birlikte nöronal kök hücre sayısının arttığı ve 1 mT'lik EMA uygulamasından 30 gün sonra bu kök hücrelerin yaklaşık \%50'sinin yetişkin hale ulaşabildiği ve DG'da sinaptik ağ vasıtası ile entegre olduğu belirtilmiştir (38). Podda ve arkadaşlarının (2014) düşük frekanslı elektromanyetik alanların ( $50 \mathrm{~Hz}=1 \mathrm{mT}$ ) fare hipokampüsünde yenidoğan nöronların hayatta kalmasına olan etkisini araştırdıkları çalışmalarında EMA'nın hipokampal nöronal kök hücre çoğalmasını ve nöronal farklılaşmasını indüklediği rapor edilmiştir (39). Loreto ve arkadaşları (2008) yetişkin sıçan kortikal nöronlarına uygulanan $50 \mathrm{~Hz}$ EMA sonucunda kültüre edilen kortikal nöronlarda apopitozise gitme oranlarının azaldığını belirtmişlerdir (40).

Bu çalışmalardan yola çıkılarak yüksek frekans aralığına sahip EMA'nın beyin, beyincik ve omurilik gibi MSS'ni oluşturan organların ve PSS'nin yapısal ve fonksiyonel yapılarının gelişiminin ve morfolojisinin üzerinde olumsuz etkilerinin olduğu söylenilebilir. Bu durumun gerek manyetik alan oluşturan pek çok cihazın beyine ve diğer sinir sistemini oluşturan organlara yakın kullanılması, gerekse EMA'ın etkilerinin ve sonuçlarının EMA'a olan mesafeye ve etki süresine bağlı olarak değişmesi ile açıklanabilir. Aynı zamanda tedavi amaçlı da kullanılabilen düşük frekans aralığına sahip EMA'nın nöronal gelişme, farklılaşma ve hayatta kalma üzerinde olumlu etkileri olabileceği de söylenilebilir.

\section{EMA ve Reprodüktif Etkileri}

Erkek üreme sisteminde spermatogenezis süreci, hipotalamus, hipofiz bezi ve testis arasındaki çapraz iletişimine dayanan karmaşık süreçlerin düzenlenmesi alındadır. Bu sürecin endokrin uyarımı, testiste Leydig hücreleri tarafından üretilen testosteron hormonu aracilıyla etki eden folikül uyarıcı hormon ve lüteinizan hormon tarafından çalıştırıır. Hormonal sinyallerin yanı sıra, sertoli hücreleri ve peritubular hücreleri spermatogenezin mitotik ve mayotik fazlarını kontrol etmek için çok sayıda büyüme faktörü ve sitokin içeren bu karmaşık sinyal oluşturma aşamalarında kilit rol rol oynamaktadırlar (41). Sommer ve arkadaşları (2009), RF'ye (özellikle Evrensel Mobil Telekomünikasyon Sistemi) sürekli maruz kalan farelerin yavrularında büyüme, gelişme ve doğurganlık potansiyelini takip etmiş ve yavruların gelişimi açısından erkek üreme sistemi üzerine hiçbir etkisi olmadığı bildirmiştir (42). Tarulli ve arkadaşları (2013) genç erkeklerde Sertoli hücrelerinin olgunlaşma ve farklılaşma sürecinin erken dönemlerinde meydana gelebilecek bozulmalar sonucunda, spermatogenezde problemler meydana gelebileceği ve bu durumun infertiliteye yol açabileceğini ifade etmektedirler (43). EMA'nın biyolojik etkilerinden biri de dokulardaki sıcaklık artışıdır. EMA altında rektal sıcaklık ve kortizol seviyeleri arasında bir ilişki olduğu ve bununda hipotalamik seviyede rol oynayan spesifik olmayan bir stres faktörü olabileceği yönünde fikirler bulunmaktadır $(44,45)$. Insan testisleri, optimum spermatogenez için vücut sıcaklığından $2 \mathrm{C}^{0}$ daha düşük fizyolojik sıcaklıklara intiyaç duyar. Yüksek yoğunluklu RF, testislerde termal etkilere yol açarak sıcakık artışına sebep olur. Maruziyete bağlı olarak, testiküler veya vücut sıcaklığındaki bir artış, spermatogenezin bozulmasına neden olabilir $(46,47)$. Mann ve arkadaşlarının 24 tane gönüllü ile 900 MHz EMA maruziyetinin kortizol seviyesindeki değişimini inceledikleri çalışmada ilk bir saat içerisinde kortizol seviyesinde geçici bir yükselme olduğunu ifade etmişler ve bu geçici değişimin nöroendokrin fonksiyonu bozduğu yönünde bir yorum yapılamayacağını bildirmişlerdir (48). Koyu ve arkadaşlarıda (2005) $900 \mathrm{MHz}$ dalga frekansında 
EMA (4 hafta/ haftada 5 gün/günde 30dk) etkisinin sıçanlarda kortizol, testosteron seviyelerini araştırmışlar ve testosteron seviyesinin EMA grubunda belirgin derecede düştüğü, kortizol seviyesinin ise arttığını belirtmişlerdir. Bu sonuçlardan yola çıkarak EMA'nın nöroendokrin sistem üzerinde etkisinin termal ve stres kaynaklı olduğunu fakat bu sonuçların fizyolojik ve morfolojik yöntemler ile desteklenmesi gerektiği kanaatine varmışlardır (49).

Sepehrimanesh ve arkadaşları (2017) 900MHz EMA'ya (30 gün/ üç farklı süre (1, 2, ve 4 saatlik) maruz bırakılan sıçanlarda testiste protein ekspresyonu inceledikleri çalışmada, 4 saatlik maruziyette nonspesifik kümelenmeyi önleyen ve fonksiyonel onarımda rol alan Isı Şok Proteinleri (Heat shock protein, HSP) ile koşaperon up-regülasyonda anormal konformasyonlar izlenmiştir (50). Odacı \& Özyılmaz'ın (2015) 30 gün boyunca günde 1 saat süre ile uyguladıkları $900 \mathrm{MHz}$ EMA maruziyetinin sıçan testis histopatolojisinde ve biyokimyasında meydana gelen değişiklikleri inceledikleri çalışmalarında seminifer tübül epitelinde ve bazal membranında ayrılma, vakuolizasyon, seminifer tübül lümeninde germinal epitel hücreleri ve intertübüler alanda ödem belirlendiğini rapor etmişlerdir (51). Özguner ve arkadaşları (2005) 869-894 MHz RF uygulamasından sonrai testis dokularında seminifer tübül çapında ve epitel kalınlığında anlamlı bir azalma meydana geldiğini ifade etmişlerdir (52). Yapılan bazı çalışmalar da prenatal ve postnatal dönemde uygulanan EMA'nın seminifer tübül çapında ve epitel kalınlı̆ında anlamlı bir azalmaya neden olduğu belirtilmiştir $(53,54)$.

Farklı frekanslardaki EMA'nın dokulardaki serbest radikallerdeki artış ile oksidatif strese neden olarak DNA fragmentasyonu, hücre bölünmesi, morfolojisi ve apoptozu, hücre zarının yapısı ve fonksiyonu ile ilgili çeşitli biyolojik etkilerinin olabileceği ortaya konulmuştur $(52,55-57)$. Oksidatif stress durumunda üretilen Reaktif oksijen türleri (ROS), DNA'daki taban ve şeker lezyonları, tek ve çift zincirli kopmalar ve DNA-protein çapraz bağlanması gibi çeşitli mekanizmalarda değişikliklere yol açar. Hancı ve arkadaşlarının (2013) prenatal dönemde (prenatal 13-21. günler) uygulanan $900 \mathrm{MHz}$ EMA'nın testis dokusu üzerine olan etkilerini inceledikleri çalışmalarında malondialdehit (MDA) seviyesinde belirgin derece artış ile birlikte TUNEL (Terminal deoxynucleotidy transferase (TdT) deoxyurıdıne triphospate nick end labeling assay) yöntemi ile apoptozis değerlendirilmesi sonucunda prenatal dönemde uygulanan EMA etkisinin postnatal süreçte bile apoptozisi tetikeleyebileceği görülmüştür (58). Farklı çalışmalarda, spermatogenik hücreler arasında apoptotik hücrelerin anlamlı derecede arttığını ifade eden raporlar mevcuttur $(59,60)$. Fakat Dasdag ve arkadaşlarının (2008) yaptıkları bir çalışma bu çalışmaların aksine cep telefonu kaynaklı EMA'nın sıçanlarda spermatogenezis sürecinde apoptozise neden olmadığını ifade etmiştir (61). Bin-Meferij MMande \& ElKott AF (2015) bir hafta boyunca günde bir saat $900 \mathrm{MHz}$
EMA etkisinin sıçan testisinde lipid peroksidasyon belirteci olan MDA seviyesinde belirgin derecede artışa, süperoksit dismutaz (SOD) ve katalaz (CAT), aktivitelerinde ise düşüşe neden olduğunu belirtmişlerdir (54). Ozguner ve arkadaşlarıda (2005) EMA'nın doku MDA seviyelerinde anlamlı derecede artış meydana geldiği belirtilirken (52), Odacı \& Özyılmaz (2015) yaptığı çalışmada bu çalışmanın aksine MDA, SOD, CAT ve glutatyon seviyelerinde anlamlı derece azalma meydana geldiği rapor etmiştir (51).

Spermatozoa plazma membranları büyük miktarlarda doymuş yağ asitleri içerir ve sitoplazmalarındaki antioksidan enzim seviyeleri çok düşüktür. Raporlar, sperm fonksiyonunun ve erkek kısırlığının ROS kaynaklı oksidatif stres tarafından etkilendiğini göstermektedir $(62,63)$. İnsanlarda, cep telefonlarııı uzun süreli kullanımı, motilite, sperm konsantrasyonu, morfoloji ile ilişkilendirilmiş (64) ve fertilite üzerine olası negatif bir etki olduğunu düşünselerde kanıtlar kafa karıştııcıdır (65). Bazı çalışmalar sperm konsantrasyonu normal iken sperm motilitesinde azalma bulmuş $(66,67)$ fakat sperm kalitesi üzerinde de bir etki bulunmamıştır (65). Nrayanan ve arkadaşlarının (2018) EMA kaynaklı oksidatif stresin sperm parametreleri üzerine etkilerini inceledikleri bir çalışmada sperm sayısında azalma gözlenmemesine rağmen motil spermde belirgin derecede azalma ve abnormal sperm sayısında ciddi artış gözlenmiş̧tir (68). Bazı hayvan çalışmalarında cep telefonu maruziyeti, sperm sayısı (69) ve motilitede (70) azalmaya neden olarak erkek fertilitesinde bozulmaya neden olduğunu söyleseler de bazı çalışmalara göre de hasar oluşturacak derecede ve süreklilikte olmadığı düşünülmektedir (71). Erkek infertilitesinde cep telefonu maruziyetinin olası bir rolünü gösteren pek çok rapora rağmen, EMA'nın erkek üreme sistemi üzerindeki etkilerinin kesin mekanizması henüz aydınlatılamamıştır.

Dünya çapında özellikle kadınlarda azalan fertilite konusundaki çalışmalara yönelim hızla artmaktadır (72). EMA'nın üreme sistemi üzerinde implantasyon bozukluğuna, konjenital malformasyona ve doğurganlık oranında azalmaya neden olabileceği düşünülmektedir. Primordiyal foliküllerin oluşumu ovaryumun fonksiyonel yönünü oluşturan folikül rezervinin kurulmasından sorumludur ve ovaryum gelişiminde kritik bir öneme sahiptir $(73,74)$. Daha önce yapıImış olan bir çalışmada prenatal ve neonatal dönemde her gün $10 \mathrm{kV} / \mathrm{m}$ EMA etkisine maruz kalan dişi sıçan üreme organında histopatolojik değişimler ve pubertaya girişte gecikme olduğu belirtilmiştir (75). $3 \mathrm{mT}$ EMA'nın ovaryum foliküllü üzerine sitotoksik etkisinin araştırıldığı çalışmada mitokondrial krista ve mikrovillus kaybı, granüloza hücrelerinde retraksiyona neden olduğu, primordiyal folikül sayısında belirgin bir azalma ile birlikte normal folikülogenezisi bozduğu düşünülmektedir (76). Yapılan bir başka çalışmada $50 \mathrm{~Hz}$ EMA etkisine maruz kalan dişi sıçanlarda implantasyonda azalmaya ve yaşayan fetüs ora- 
nında düşüşe neden olduğu belirtilmiştir (77). Türedi ve arkadaşları (2016) $900 \mathrm{MHz}$ EMA (prenatal dönem/ günde 1 saat) maruziyetinin dişi sıçanların ovaryum dokusunda granüloza hücrelerinde belirgin dejenerasyon ve vakuolizasyon, apoptozis ile birlikte primordial ve tersiyer folikül sayısında belirgin derecede azalma olduğunu belirtmiştir (78). Okatan ve arkadaşlarının (2018) orta ve geç adolesan dönemde günde bir saat $900 \mathrm{MHz}$ EMA etkisine maruz kalan dişi sıçanların primordiyal folikül sayısının normal olduğu, sekonder folikül sayısının belirgin derecede azaldığı, Apoptotik Indeksin anlamlı olmadığı görülmüştür. Ek olarak SOD, CAT, anti-Müller hormon, 3-nitrotirozin seviyelerinde artış olduğu belirtilmiş ve erken-geç adolesan dönemde EMA maruziyetinin morfolojik ve biyokimyasal açıdan ovaryum hasarına neden olabileceğini rapor etmişlerdir (79).

EMA'nın ovaryum hasarı üzerine yapılan çalışmalar incelendiğinde pek çoğunun düşük şiddetteki EMA maruziyetine bağlı hasar geliştiğine yönelik bulgular görülmektedir. Fakat cep telefonu kaynaklı $900 \mathrm{MHz}$ EMA etkisinin ovaryum hasarının araştıııldığı çalışmaların yetersiz olması, bu konuda farklı doz ve süreler ile daha çok çalışmaya ihtiyaç duyulduğuna dikkat çekmektedir.

\section{EMA ve Kardiyovasküler Etkileri}

Kalp kendi ritmini oluşturan ve sürekli kasılan bir organ olmakla birlikte karakteristik uyarılma özelliğinden dolayı kalbin kasılması ya da ritmi dış uyaranlar tarafından etkilenebilir (80). Braune ve arkadaşları (1998), gönüllü kişiler üzerinde EMA'nın kardiyovasküler sistem üzerindeki etkilerini araştırmışlar ve 35 dakika boyunca 900 MHz'de EMA'ya maruz bırakıldıklarında kan basıncında (hem sistolik hem de diyastolik) bir artış olduğunu, vazokonstriksiyona bağlı kılcal perfüzyonda önemli bir azalma ile birlikte kalp hizında bir azalma olduğu belirtilmiştir (81). Önceki bulgularını doğrulamak için yapılan bir takip çalışmalarında, kan basıncında istatistiksel olarak anlamlı bir artış gösterilmiştir, ancak varyans analizi, değişikliklerin EMA maruziyetinden bağımsız olduğunu göstermiştir (82). Tahvanainen ve arkadadaşları (2004), cep telefonu maruziyetinin arteriyel kan basıncını ve kalp atış hızını akut olarak değiştirmediği rapor edilmişlerdir $(9,83)$.

Gelişim sürecinin çevresel faktörlerden en fazla etkilendiği dönem prenatal dönemdir (84). EMA'nın, prenatal dönemdeki embriyo ve fetus üzerine olan etkileri ciddi tartışma konularındandır. Türedi ve arkadaşlarının (2015) prenatal dönemin 13-21. günler arası $900 \mathrm{MHz}$ EMA'ya maruz kalan yavru sıçanların kalp dokusundaki etkilerini araştırdıkları çalışmada oksidan-antioksidan dengenin bozulduğu ve kardiyomiyositlerde DNA fragmentasyonu açısından TUNEL tekniği kullanılarak değerlendirilen apoptozisin belirgin derecede arttığı izlenmiş̧ir. Elektron mikroskopik incelemelerde ise mitokondriyal şişkinlik ve krista kaybı, myofibrillerde dejenerasyon ve $Z$ bantlarında yapısal bozulmalar izlendiği belirtilmiştir (85). Özguner ve ark. (2005), 900
MHz'e (10 gün boyunca 30 dakika / gün) maruz kaldığında sıçan miyokardında oksidatif stres belirteçlerinin arttığı ve antioksidan parametrelerde bozulma ile birlikte oksidanantioksidan dengeyi etkileyebileceği belirtilmişstir (86). Ye ve arkadaşlarının (2015) tavuk embriyolarında cep telefonu kaynaklı EMA maruziyetinin kardiyolojik etkilerini inceledikleri çalışmalarında inkübasyonun 15-21. günlerinde miyofilaman bozulması, atriyoventriküler kapak fokal nekrozu, mitokondri vakuolizasyonu ve atriyal natriüretik peptit azalması gibi bulguları aktarmışlardır (87). Parazzini ve arkadaşları (2007) 26 adet gönüllü üzerinde cep telefonunun kalp hızı üzerine etkisi olup olmadığını araştırmışlar ve sonucun istatisiksel açıdan anlamlı bir değer olmadığı görülmüştür (88).

Yapılan çalışmalara göre, $900 \mathrm{MHz}$ EMA etkisinin kalp dokusunda hasar meydana geldiğini destekleyecek çok azdır ve insan sağlığı açısından cep telefonu kaynaklı EMA maruziyeti hala tartışmalı bir konudur.

\section{Sonuç}

Gelişen modern teknolojiler ile birlikte cep telefonları/akıllı telefonlar günlük yaşamın hayati bir parçasıdır ve kullanımının olumlu/olumsuz sonuçlarını değerlendirmek için ek çalışmalara intiyaç vardır. Gelecekte yapılacak olan çalışmaların sonuçları ortaya çıkıncaya kadar maalesef bu tartışma ve endişeler devam edecektir. Tüm incelenen literatür kaynaklardan yola çıkılarak, yüksek frekans aralığına sahip EMA'nın MSS ve PSS'nin yapısal ve fonksiyonel gelişiminin üzerinde olumsuz etkilerinin olduğu söylenilebilir. Erkek infertilitesinde cep telefonu maruziyetinin olası bir rolünü gösteren pek çok rapor bulunmakla birlikte EMA'nın erkek üreme sistemi üzerindeki etkilerinin kesin mekanizması henüz aydınlatımamışıı. İncelenen literatür kaynaklara bakıldığında $900 \mathrm{MHz}$ EMA etkisinin kalp dokusunda meydana gelebilecek biyolojik hasar açısından maalesef çok az çalışma vardır ve insan sağlığı açısından cep telefonu kaynaklı EMA maruziyetinin sonuçları birbiri ile tartışmalı bir konudur. EMA'nın ovaryum hasarı üzerine yapılan çalışmalar incelendiğinde cep telefonu kaynaklı $900 \mathrm{MHz}$ EMA etkisinin ovaryum hasarı açısından çalışmaların araştırmaların yetersizliği, bu konuda farklı doz ve süreler ile birlikte yeni modern metodlar kullanılarak daha çok çalışmaların yapılması için araştırmacılar desteklenmelidir.

Çıkar Çatışması: Yazarlar arasında finansal ve ticari çıkarları olmadığı beyan edilmiş ve çıkar çatışması olmadığı bildirilmiştir.

\section{Kaynaklar}

1. Feychting M, Ahlbom A, Kheifets L. EMF and Health. Annu Rev Public Health. 2005; 26:165-89.

2. Koca O, Gökçe AM, Öztürk MI, Ercan F, Yurdakul N, Karaman MI. Effects of intensive cell phone (Philips Genic 900) use on the rat kidney tissue. Urol J. 2013; 10(2):886-91.

3. Huber R, Graf T, Cote KA, Wittmann L, Gallmann E, Matter D, et al. 
Exposure to pulsed high-frequency electromagnetic field during waking affects human sleep EEG. Neuroreport. 2000; 11(15):3321-5.

4. Kennedy G E, Judd TS, Churchward A, Gray K, Krause KL. First year students' experiences with technology: Are they really digital natives? AJET. 2008; 24(1): 108-22.

5. Bian M. and Leung L. Linking Loneliness, Shyness, Smartphone Addiction Symptoms, and Patterns of Smartphone Use to Social Capital. SSCR. 2015;33(1):61-79.

6. Davis DL, Kesari S, Soskolne CL, Miller AB, Stein Y. Swedish review strengthens grounds for concluding that radiation from cellular and cordless phones is a probable human carcinogen. Pathophysiology. 2013; 20(2):123-9.

7. Türkan A, Pala K. Çok düşük frekanslı elektromanyetik radyasyon ve sağlık etkileri. Uludağ Üniversitesi Mühendislik-Mimarlık Fakültesi Dergisi. 2009; 14: (2)11-22.

8. Jooyan N, Goliaei B, Bigdeli B, Faraji-Dana R, Zamani A, Entezami $M$, et al. Direct and indirect effects of exposure to $900 \mathrm{MHz}$ GSM radiofrequency electromagnetic fields on $\mathrm{CHO}$ cell line: Evidence of bystander effect by non-ionizing radiation. Environ Res. 2019; 174:176-87.

9. Makker K, Varghese A, Desai NR, Mouradi R, Agarwal A. Cell phones: modern man's nemesis? Reprod Biomed Online. 2009;18(1):14857.

10. Aslan A, Aydoğan NH, Atay T, Çömlekçi S. Cep telefonlarından yayılan $900 \mathrm{mhz}$ frekans elektromanyetik alana kısa ve uzun dönem maruziyetin sıçanların kemik dokusu üzerine etkisi. Dicle Tıp Dergisi.2011; 38 (4): 452-7.

11. Bhat MA. Effects of electromagnetic waves emitted by mobile phones on male fertility. CEIS. 2013; 4(3):51-64.

12. Türkiye İstatistik Kurumu (TÜIK). TÜIK, Hanehalkı Bilişim Teknolojileri Kullanım Araştırması, 2004-2019. 2019; Available from: http://tuik.gov.tr/PreTablo.do?alt_id=1028.

13. Erdoğan M, Şahin E, Dinçer S. Elektromanyetik Alan Oluşturan Cihazlar Sanıldığı Kadar Masum Mu? Derleme. Journal of Human Rhythm. 2019;5(1):41-53.

14. Agarwal A, Singh A, Hamada A, Kesari K. Cell phones and male infertility: a review of recent innovations in technology and consequences. Int Braz J Urol. $2011 ; 37(4)$ :432-54.

15. Aslan A. Düșük ve Yüksek Frekans Elektromanyetik Alanların Kırık İyileșmesine Etkileri. Kafkas Tıp Bilimleri Dergisi. 2(1):34-42.

16. Hancı H: Prenatal Dönemde Uygulanan $900 \mathrm{MHz}$ Elektromanyetik Alanın Sıçan Periferik Sinir Morfolojisi ve Fonksiyonuna Etkisi: Doktora Tezi, Trabzon: Karadeniz Teknik Üniversitesi Sağlık Bilimleri Enstitüsü, 2019.

17. Saygın M, Çalışkan S, Gümral N, Bocutoğlu AÇ, Has M. $2450 \mathrm{MHz}$ Elektromanyetik alan ve karaciğer üzerine etkileri. Süleyman Demirel Üniversitesi Sağlık Bilimleri Enstitüsü Dergisi. 2010; 1(1):16-22.

18. International Commission on Non-lonizing Radiation Protection: Guidelines for Limiting Exposure to Time Varying Electric, Magnetic and Electromagnetic Fields (Up To $300 \mathrm{GHz}$ ). Health Physics. 1998; 74: 494-522. Available from: https://www.icnirp.org/cms/upload/publications/ICNIRPemfgdl.pdf

19. Federal Communications Commission Office of Engineering \& Technology. Questions and Answers About Biological Effects and Potential Hazards of Radiofrequency Electromagnetic Fields. 1999; Oet Bulletin 56. Fourth Edition 5-38. Available from: https://transition.fcc.gov/Bureaus/Engineering_Technology/Documents/bulletins/oet56/oet56e4.pd

20. TUBITAK Bilten (2001). Elektromanyetik dalgalar ve insan sağlığ sıkça sorulan sorular ve yanıtları (Electromagnetic waves and human health, frequently asked questions and answers) (Electronic version, article in Turkish) Retrived February 20. 2015; Available from http://www.biltek.tubitak.gov.tr/sandik/gsm.pdf

21. Behari J. Biological correlates of electromagnetic field exposure. IETE Technical Review. 2003; 20(2): 165-74.

22. Nittby H, Brun A, Eberhardt J, Malmgren L, Persson BR, Salford LG. Increased blood-brain barrier permeability in mammalian brain 7 days after exposure to the radiation from a GSM-900 mobile phone. Pathophysiology. 2009; 16(2-3):103-12.

23. Clelland CD, Choi M, Romberg C, Clemenson GD Jr, Fragniere A, Tyers $P$, et al. A functional role for adult hippocampal neurogenesis in spatial pattern separation. Science. 2009; 325(5937):210-3.

24. Odacı E, Bas O, Kaplan S. Effects of prenatal exposure to a 800 $\mathrm{MHz}$ electromagnetic field on the dentate gyrus of rats: a stereological and histopathological study. Brain Res. 2008; 1238:224-9.

25. Baş O, Sönmez FO, Aslan A, İkinci A, Hancı H, Yıldııım M, et al. Pyramidal cell loss in the cornu ammonis of 32-day-old female rats following exposure to a 900 Megahertz electromagnetic field during prenatal days. Neuroquantology. 2013; 11(4):591-9.

26. Kerimoğlu G, Hancı H, Baş O, Aslan A, Erol HS, Turgut A, et al. Pernicious effects of long-term, continuous $900-\mathrm{MHz}$ electromagnetic field throughout adolescence on hippocampus morphology, biochemistry and pyramidal neuron numbers in 60-day-old Sprague Dawley male rats. J Chem Neuroanat. 2016a; 77:169-75.

27. Balaguru S, Uppal R, Vaid RP, Kumar BP. Investigation of the spinal cord as a natural receptor antenna for incident electromagnetic waves and possible impact on the central nervous system. Electromagn Biol Med. 2012; 31(2):101-11.

28. Odacı E, İkinci A, Yıldırım M, Kaya H, Akça M, Hancı H, et al. The effects of 900 megahertz electromagnetic field applied in the prenatal period on spinal cord morphology and motor behavior in female rat pups. NeuroQuantology. 2013; 11(4):573-81.

29. Ammari M, Jeljeli M, Maaroufi K, Roy V, Sakly M, Abdelmelek $H$. Static magnetic field exposure affects behavior and learning in rats. Electromagn Biol Med. 2008; 27(2):185-96.

30. Kerimoğlu G, Aslan A, Baş O, Çolakoğlu S, Odacı E. Adverse effects in lumbar spinal cord morphology and tissue biochemistry in Sprague Dawley male rats following exposure to a continuous 1-h a day 900$\mathrm{MHz}$ electromagnetic field throughout adolescence. J Chem Neuroanat. 2016b; 78:125-30.

31. Sonmez OF, Odaci E, Bas O, Kaplan S. Purkinje cell number decreases in the adult female rat cerebellum following exposure to $900 \mathrm{MHz}$ electromagnetic field. Brain Res. 2010; 1356:95-101.

32. Odacı E, Hancı H, İkinci A, Sönmez OF, Aslan A, Şahin A, et al. Maternal exposure to a continuous $900-\mathrm{MHz}$ electromagnetic field provokes neuronal loss and pathological changes in cerebellum of 32-dayold female rat offspring. J Chem Neuroanat. 2016; 75(Pt B):105-10.

33. Haghani M, Shabani M, Moazzami K. Maternal mobile phone exposure adversely affects the electrophysiological properties of Purkinje neurons in rat offspring. Neuroscience. 2013; 250:588-98.

34. Kaplan S, Odaci E, Unal B, Sahin B, Fornaro M. Chapter 2: Development of the peripheral nerve. Int Rev Neurobiol. 2009; 87: 9-26.

35. Kerns JM. The microstructure of peripheral nerves. Techniques in Regional Anesthesia and Pain Management. 2008; 12(3):127-33.

36. Choi S, Choi HJ, Cheong Y, Lim YJ, Park HK. Internal-specific morphological analysis of sciatic nerve fibers in a radiofrequency-induced animal neuropathic pain model. PLoS One. 2013; 8(9):e73913.

37. Comelekoglu U, Aktas S, Demirbag B, Karagul MI, Yalin S, Yildirim $\mathrm{M}$, et al. Effect of low-level $1800 \mathrm{MHz}$ radiofrequency radiation on the rat sciatic nerve and the protective role of paricalcitol. Bioelectromagnetics. 2018; 39(8):631-43.

38. Piacentini R, Ripoli C, Mezzogori D, Azzena GB, Grassi C. Extremely low-frequency electromagnetic fields promote in vitro neurogenesis via upregulation of $\mathrm{Ca}(\mathrm{v}) 1$-channel activity. J Cell Physiol. 2008; 215(1):129-39.

39. Podda MV, Leone L, Barbati SA, Mastrodonato A, Li Puma DD, Piacentini $R$, et al. Extremely low-frequency electromagnetic fields enhance the survival of newborn neurons in the mouse hippocampus. Eur J Neurosci. 2014; 39(6):893-903.

40. Loreto SD, Falone S, Caracciolo V, Sebastiani P, D'Alessandro A, Mirabilio A, et al. Fifty hertz extremely low-fraquency magnetic field exposure elicits redox and trophic response in rat - cortical neurons. J Cell Physiol. 2009; 219(2):334-43. 
41. Santini SJ, Cordone V, Falone S, Mijit M, Tatone C, Amicarelli F, et al. Role of Mitochondria in the Oxidative Stress Induced by Electromagnetic Fields: Focus on Reproductive Systems. Oxid Med Cell Longev. 2018; 8;2018:5076271. doi: 10.1155/2018/5076271.

42. Sommer AM, Grote K, Reinhardt T, Streckert J, Hansen V, Lerchl A. Effects of radiofrequency electromagnetic fields (UMTS) on reproduction and development of mice: a multi-generation study. Radiat Res. 2009; 171(1):89-95.

43. Tarulli GA, Stanton PG, Loveland KL, Rajpert-De Meyts E, McLachlan R, Meachem SJ. A survey of Sertoli cell differentiation in men after gonadotropin suppression and in testicular cancer. Spermatogenesis. 2013; 3(1):e24014.

44. Lotz WG, Michaelson SM. Temperature and corticosterone relationships in microwave-exposed rats. J Appl Physiol Respir Environ Exerc Physiol. 1978; 44(3):438-45.

45. Lotz WG, Podgorski RP. Temperature and adrenocortical responses in rhesus monkeys exposed to microwaves. J Appl Physiol Respir Environ Exerc Physiol. 1982; 53(6):1565-71.

46. Kandeel FR, Swerdloff RS. Role of temperature in regulation of spermatogenesis and the use of heating as a method for contraception. Fertil Steril. 1988; 49(1):1-23.

47. Jung A, Schill WB. Male infertility. Current life style could be responsible for infertility. MMW Fortschritte der Medizin. 2000; 142(37):31-33. 48. Mann K, Wagner P, Brunn G, Hassan F, Hiemke C, Röschke J. Effects of pulsed high-frequency electromagnetic fields on the neuroendocrine system. Neuroendocrinology. 1998; 67(2):139-44.

49. Koyu A, Cesur G, Özgüner F, Elmas O. Cep telefonlarından yayılan $900 \mathrm{MHz}$ elektromanyetik alanın serum kortizol ve testosteron hormonu üzerine etkisi. Süleyman Demirel Üniversitesi Tıp Fakültesi. 2005; 12(01): 52-6.

50. Sepehrimanesh M, Kazemipour N, Saeb M, Nazifi S, Davis DL. Proteomic analysis of continuous $900-\mathrm{MHz}$ radiofrequency electromagnetic field exposure in testicular tissue: a rat model of human cell phone exposure. Environ Sci Pollut Res Int. 2017;24(15):13666-73.

51. Odacı E, Özyılmaz C. Exposure to a $900 \mathrm{MHz}$ electromagnetic field for 1 hour a day over 30 days does change the histopathology and biochemistry of the rat testis. Int J Radiat Biol. 2015; 91(7):547-54.

52. Ozguner M, Koyu A, Cesur G, Ural M, Ozguner F, Gokcimen A, et al. Biological and morphological effects on the reproductive organ of rats after exposure to electromagnetic field. Saudi Med J. 2005;26(3):40510.

53. Tenorio BM, Jimenez GC, Morais RN, Torres SM, Nogueira RA, Junior VAS. Testicular development evaluation in rats exposed to $60 \mathrm{~Hz}$ and $1 \mathrm{mT}$ electromagnetic field. J Appl Toxicol. 2011; 31(3):223-30.

54. Bin-Meferij MM, El-Kott AF. The radioprotective effects of Moringa oleifera against mobile phone electromagnetic radiation-induced infertility in rats. Int J Clin Exp Med. 2015; 8(8):12487-97.

55. Tayefi H, Kiray A, Kiray M, Ergur BU, Bagriyanik HA, Pekcetin C, et al. The effects of prenatal and neonatal exposure to electromagnetic fields on infant rat myocardium. Arch Med Sci. 2010; 6(6):837-42.

56. Lu YS, Huang BT, Huang YX. Reactive oxygen species formation and apoptosis in human peripheral blood mononuclear cell induced by $900 \mathrm{MHz}$ mobile phone radiation. Oxid Med Cell Longev. 2012:740280. 57. Türedi S, Kerimoğlu G, Mercantepe T, Odacı E. Biochemical and pathological changes in the male rat kidney and bladder following exposure to continuous $900-\mathrm{MHz}$ electromagnetic field on postnatal days $22-$ 59. Int J Radiat Biol. 2017; 93(9):990-9.

58. Hancı H, Odacı E, Kaya H, Aliyazıcıoğlu Y, Turan I, Demir S, et al. The effect of prenatal exposure to $900-\mathrm{MHz}$ electromagnetic field on the 21-old-day rat testicle. Reprod Toxicol. 2013;42:203-9.

59. Beumer TL, Roepers-Gajadien HL, Gademan IS, Lock TM, Kal HB, De Rooij DG. Apoptosis regulation in the testis: involvement of $\mathrm{Bcl}-2$ family members. Mol Reprod Dev. 2000; 56(3):353-9.

60. Saygin M, Caliskan S, Karahan N, Koyu A, Gumral N, Uguz A. Testicular apoptosis and histopathological changes induced by a $2.45 \mathrm{GHz}$ electromagnetic field. Toxicol Ind Health. 2011; 27(5):455-63.
61. Dasdag S, Akdag MZ, Ulukaya E, Uzunlar AK, Yegin D. Mobile phone exposure does not induce apoptosis on spermatogenesis in rats. Arch. Med. Res. 2008; 39(1):40-4.

62. Sikka SC. Oxidative stress and role of antioxidants in normal and abnormal sperm function. Front Biosci. 1996;1:e78-86.

63. Lavranos G, Balla M, Tzortzopoulou A, Syriou V, Angelopoulou R. Investigating ROS sources in male infertility: A common end for numerous pathways. Reprod Toxicol. 2012; 34(3):298-7.

64. Agarwal A, Deepinder F, Sharma RK, Ranga G, Li J. Effect of cell phone usage on semen analysis in men attending infertility clinic: an observational study. Fertil Steril. 2008; 89(1):124-8.

65. Adams JA, Galloway TS, Mondal D, Esteves SC, Mathews F. Effect of mobile telephones on sperm quality: a systematic review and metaanalysis. Environ Int. 2014;70:106-12.

66. Fejes I, Závaczki Z, Szöllosi J, Koloszár S, Daru J, Kovács L, et al. Is there a relationship between cell phone use and semen quality? Arch Androl. $2005 ; 51(5): 385-93$

67. Erogul O, Oztas E, Yildirim I, Kir T, Aydur E, Komesli G, et al. Effects of electromagnetic radiation from a cellular phone on human sperm motility: An in vitro study. Arch Med Res. 2006;37(7):840-3.

68. Narayanan SN, Lukose ST, Arun G, Mohapatra N, Pamala J, Concessao PL, et al. Modulatory effect of $900 \mathrm{MHz}$ radiation on biochemical and reproductive parameters in rats. Bratisl Lek Listy. 2018;119(9):5817.

69. Kesari KK, Kumar S, Behari J. Mobile phone usage and male infertility in Wistar rats. Indian J Exp Biol. 2010; 48(10):987-92.

70. Mailankot M, Kunnath AP, Jayalekshmi H, Koduru B, Valsalan R. Radio frequency electromagnetic radiation (RF-EMR) from GSM $(0.9 / 1.8 \mathrm{GHz})$ mobile phones induces oxidative stress and reduces sperm motility in rats. Clinics (Sao Paulo). 2009;64(6):561-5.

71. Dasdag S, Zulkuf Akdag M, Aksen F, Yilmaz F, Bashan M, Mutlu Dasdag M, et al. Whole body exposure of rats to microwaves emitted from a cell phone does not affect the testes. Bioelectromagnetics. 2003; 24(3):182-8.

72. Martinez G, Daniels K, Chandra A. Fertility of men and women aged 15-44 years in the United States: National Survey of Family Growth, 2006-2010. Natl Health Stat Report. 2012; 12(51):1-28.

73. Hirshfield AN. Development of follicles in the mammalian ovary. Int Rev Cytol. 1991;124:43-101.

74. Gaytán F, Morales C, Manfredi-Lozano M, Tena-Sempere M. Generation of multi-oocyte follicles in the peripubertal rat ovary: link to the invasive capacity of granulosa cells? Fertil Steril. 2014;101(5):1467-76. 75. Gharamaleki H, Parivar K, Rad JS, Roushangar L, Shariati M. Effects of extremely low-frequency electromagnetic field exposure durıng the prenatal period on biomarkers of oxidative stress and pathology of ovarian tissue in F1 generation. Int J Curr Res Rev. 2013; 5(21):23-9.

76. Roushangar L, Hamdi BA, Khaki AA, Rad JS, Soleimani-Rad S. Effect of low-frequency electromagnetic field exposure on oocyte differentiation and follicular development. Adv Biomedl Res. 2014; 27:3-76. 77. Al-Akhras MA, Elbetieha A, Hasan MK, Al-Omari I, Darmani H, Albiss $B$. Effects of extremely low frequency magnetic field on fertility of adult male and female rats. Bioelectromagnetics. 2001; 22(5):340-4.

78. Türedi S, Hancı H, Çolakoğlu S, Kaya H, Odacı E. Disruption of the ovarian follicle reservoir of prepubertal rats following prenatal exposure to a continuous 900-MHz electromagnetic field. Int J Radiat Biol. 2016; 92(6):329-37.

79. Okatan DÖ, Kaya H, Aliyazıcıoğlu Y, Demir S, Çolakoğlu S, Odacı E. Continuous 900 -megahertz electromagnetic field applied in middle and late-adolescence causes qualitative and quantitative changes in the ovarian morphology, tissue and blood biochemistry of the rat. Int J Radiat Biol. 2018; 94(2):186-98.

80. Elmas O, Comlekci S, Koylu H. Effects of short-term exposure to powerline-frequency electromagnetic field on the electrical activity of the heart. Arch Environ Occup Health. 2012;67(2):65-71.

81. Braune S, Wrocklage C, Raczek J, Gailus T, Lücking $\mathrm{CH}$. Resting 
blood pressure increase during exposure to a radio-frequency electromagnetic field. Lancet. 1998; 351(9119):1857-8.

82. Braune S, Riedel A, Schulte-Mönting J, Raczek J. Influence of a radiofrequency electromagnetic field on cardiovascular and hormonal parameters of the autonomic nervous system in healthy individuals. Radiat Res. 2002; 158(3):352-6.

83. Tahvanainen K, Niño J, Halonen P, Kuusela T, Laitinen T, Länsimies $\mathrm{E}$, et al. Cellular phone use does not acutely affect blood pressure or heart rate of humans. Bioelectromagnetics. 2004; 25(2):73-83.

84. Poulletier de Gannes F, Haro E, Hurtier A, Taxile M, Athane A, AitAissa S, et al. Effect of in utero wi-fi exposure on the pre- and postnatal development of rats. Birth Defects Res B Dev Reprod Toxicol. 2012; 95(2):130-6.

85. Türedi S, Hancı H, Topal Z, Ünal D, Mercantepe T, Bozkurt I, et al. The effects of prenatal exposure to a $900-\mathrm{MHz}$ electromagnetic field on the 21-day-old male rat heart. Electromagn Biol Med. 2015;34(4):3907.

86. Ozguner F, Altinbas A, Ozaydin M, Dogan A, Vural H, Kisioglu AN, et al. Mobile phone-induced myocardial oxidative stress: protection by a novel antioxidant agent caffeic acid phenethyl ester. Toxicol Ind Health. 2005; 21(9):223-30.

87. Ye W, Wang F, Zhang W, Fang N, Zhao W, Wang J. Effect of Mobile Phone Radiation on Cardiovascular Development of Chick Embryo. Anat Histol Embryol. 2016; 45(3):197-208.

88. Parazzini M, Ravazzani P, Tognola G, Thuróczy G, Molnar FB, Sacchettini A, et al. Electromagnetic fields produced by GSM cellular phones and heart rate variability. Bioelectromagnetics. 2007; 28(2):1229 